\title{
PALEOHYDRAULIC MODELLING OF OUTBURST FLOODS FROM NEOGLACIAL LAKE ALSEK, YUKON TERRITORY, CANADA
}

\section{(Abstract)}

by

\author{
Garry K.C. Clarke
}

(Department of Geophysics and Astronomy, University of British Columbia, Vancouver, British Columbia V6T 1W5, Canada)

Neoglacial Lake Alsek is a glacier-dammed lake that forms when surge advances of Lowell Glacier block the normal flow of Alsek River. When filled to the highest level, the reservoir held approximately $30 \mathrm{~km}^{3}$ of water and is believed to have been the largest ice-dammed lake to form since the end of the Wisconsin glaciation. One or more fillings in the twentieth century have been comparatively minor, impounding less than $2 \mathrm{~km}^{3}$ of water. Future fillings of Neoglacial Lake Alsek could have two main human impacts: (1) the level of impounded water could rise to inundate the town of Haines Junction and sections of the Haines and Alaska Highways; (2) catastrophic outburst floods could endanger down-stream development.

Over the past decade we have collected data on the reservoir geometry, the elevation of staircase beaches, the geometry of giant current ripple-marks, and the sedimentology of ponds that lie within the margins of Lake Alsek. These data cast light on various aspects of the history of cyclic filling and outburst flooding from the reservoir and can be synthesized to construct a paleohydraulic simulation model. Two past filling events (see Clague and Rampton, 1982) are singled out for analysis: a filling to $595 \mathrm{~m}$ a.s.l. occurred c. 1850 and impounded $4.7 \mathrm{~km}^{3}$ of water. A filling to $678 \mathrm{~m}$ a.s.l. occurred at some earlier time and impounded $2.84 \mathrm{~km}^{3}$ of water; this filling, though high, is not perhaps the maximum filling. Calculations using a previously described computer model (Clarke, 1982; Clarke and others, 1984) place the peak discharge of these two outbursts at roughly $3.0 \times 10^{4}$ and $4.7 \times 10^{5} \mathrm{~m}^{3} \mathrm{~s}^{-1}$, respectively. If accurate, the latter estimate would establish the maximum floods from Neoglacial Lake Alsek as the greatest floods that have occurred since the end of the Wisconsin glaciation. For comparison, the mean discharge of all the world's rivers to oceans is $1.2 \times 10^{6} \mathrm{~m}^{3} \mathrm{~s}^{-1}$.

Dunes constructed from cobble-sized material are found in the present (subaerial) lake bed. These bed forms yield constraints on the hydraulic conditions that must have existed during past floods: (1) Water level must have exceeded the height of the dune features at the time they were formed. (2) Bed shear stress must have been sufficiently high to mobilize the coarse-grained material from which the dunes are constructed. (3) The Froude number must have been near 1.0 (actually somewhat less than 1.0 but this nicety adds nothing to a rough model) when the dunes were formed. These constraints on dune development can be used to test the model predictions against field observations that dunes can be observed as far up-stream as $47.2 \mathrm{~km}$ from the former ice dam. The approach followed in the paleohydraulic modelling is to generate a computer-predicted discharge hydrograph $Q(0, t)$ for each flood and from this to calculate $Q(\ell, t)$, the discharge $Q$ as a function of time $t$, and up-stream distance $\ell$ from the ice dam located at $\ell=0$. Let $A\left(\ell, z_{w}\right)$ be the up-stream reservoir area (for a water level $z_{w}$ at a distance $\ell$ up-stream from the ice dam) and $S\left(\ell, z_{\mathrm{w}}\right)$ be the cross-sectional area of the channel. From the model-generated hydrograph $Q(0, t)$ and water level $z_{\mathrm{w}}(t)$, the following can be calculated:

$$
\begin{aligned}
Q(\ell, t) & =-A\left(\ell, z_{\mathrm{w}}\right) \frac{\mathrm{d} z_{\mathrm{w}}}{\mathrm{d} t} \quad(\text { discharge at up-stream distance } \ell) \\
u(\ell, t) & =\frac{Q}{S} \quad \text { (mean velocity) } \\
F r(\ell, t) & =\frac{u}{\left[g\left(z_{\mathrm{W}}-z_{\text {floor }}\right)\right)^{\frac{1}{2}}} \text { (Froude number) } \\
\tau_{0}(\ell, t) & =\frac{1}{2} c_{\mathrm{f}} \rho_{\mathrm{w}} u^{2} \text { (bed shear) } \\
D(\ell, t) & =\frac{\tau_{0}}{0.06\left(\rho_{\mathrm{S}}-\rho_{\mathrm{w}}\right) g} \quad \begin{array}{c}
\text { (grain diameter from Shield's } \\
\text { condition) }
\end{array}
\end{aligned}
$$

where $z_{\text {floor }}$ is elevation of valley floor; $c_{\mathrm{f}}$ is frictional drag coefficient; $\rho_{\mathrm{w}}$ is density of water; $D$ is grain diameter $(\mathrm{mm}) ; \rho_{\mathrm{S}}$ is grain density; $g$ is gravitational acceleration. The paleohydraulic calculations of $h(\ell, l)=z_{\mathrm{w}}(t)-z_{\text {floor }}(\ell)$, $\operatorname{Fr}(\ell, t)$, and $D(\ell, t)$ reveal that the predicted flood for the $678 \mathrm{~m}$ a.s.l. filling could have generated the existing bed forms but the $595 \mathrm{~m}$ a.s.l. flood could not. This test indicates that only a very great flood could have created the bed forms now found in the Lake Alsek bed.

\section{REFERENCES}

Clague, J.J. and V.N. Rampton. 1982. Neoglacial Lake Alsek. Can. J. Earth Sci., 19(1), 94-117.

Clarke, G.K.C. 1982. Glacier outburst floods from "Hazard Lake", Yukon Territory, and the problem of flood magnitude prediction. J. Glaciol., 28(98), 3-21.

Clarke, G.K.C., W.H. Mathews, and R.T. Pack. 1984. Outburst floods from glacial Lake Missoula. Quat. Res. 22(3), 289-299. 